\title{
Locations and Attributes of Wind Turbines in Colorado, 2011
}

By Natasha B. Carr, James E. Diffendorfer, Tammy Fancher, Sarah J. Hawkins, Natalie Latysh, Kenneth J. Leib, and Anne Marie Matherne

2013

U.S. Geological Survey Data Series 782

\section{Abstract}

This dataset represents an update to U.S. Geological Survey Data Series 597. Locations and attributes of wind turbines in Colorado, 2009 (available at http://pubs.usgs.gov/ds/597/). This updated Colorado wind turbine Data Series provides geospatial data (fig. 1) for all 1,204 wind turbines established within the State of Colorado as of September 2011, an increase of 297 wind turbines from 2009.

Attributes specific to each turbine include: turbine location, manufacturer and model, rotor diameter, hub height, rotor height, potential megawatt output, land ownership, county, and development status of the wind turbine. Wind energy facility data for each turbine include: facility name, facility power capacity, number of turbines associated with each facility to date, facility developer, facility ownership, and year the facility went online. The locations of turbines are derived from 1-meter true-color aerial photographs produced by the National Agriculture Imagery Program (NAIP); the photographs have a positional accuracy of about \pm 5 meters. Locations of turbines constructed during or prior to August 2009 are based on August 2009 NAIP imagery and turbine locations constructed after August 2009 were based on September 2011 NAIP imagery. The location of turbines under construction during September 2011 likely will be less accurate than the location of existing turbines.

This data series contributes to an Online Interactive Energy Atlas developed by the U.S. Geological Survey (http://my.usgs.gov/eerma/). The Energy Atlas synthesizes data on existing and potential energy development in Colorado and New Mexico and includes additional natural resource data layers. This information may be used by decisionmakers to evaluate and compare the potential benefits and tradeoffs associated with different energy development strategies or scenarios. Interactive maps, downloadable data layers, comprehensive metadata, and decisionsupport tools also are included in the Energy Atlas. The format of the Energy Atlas is designed to facilitate the integration of information about energy with key terrestrial and aquatic resources for evaluating resource values and minimizing risks from energy development. 


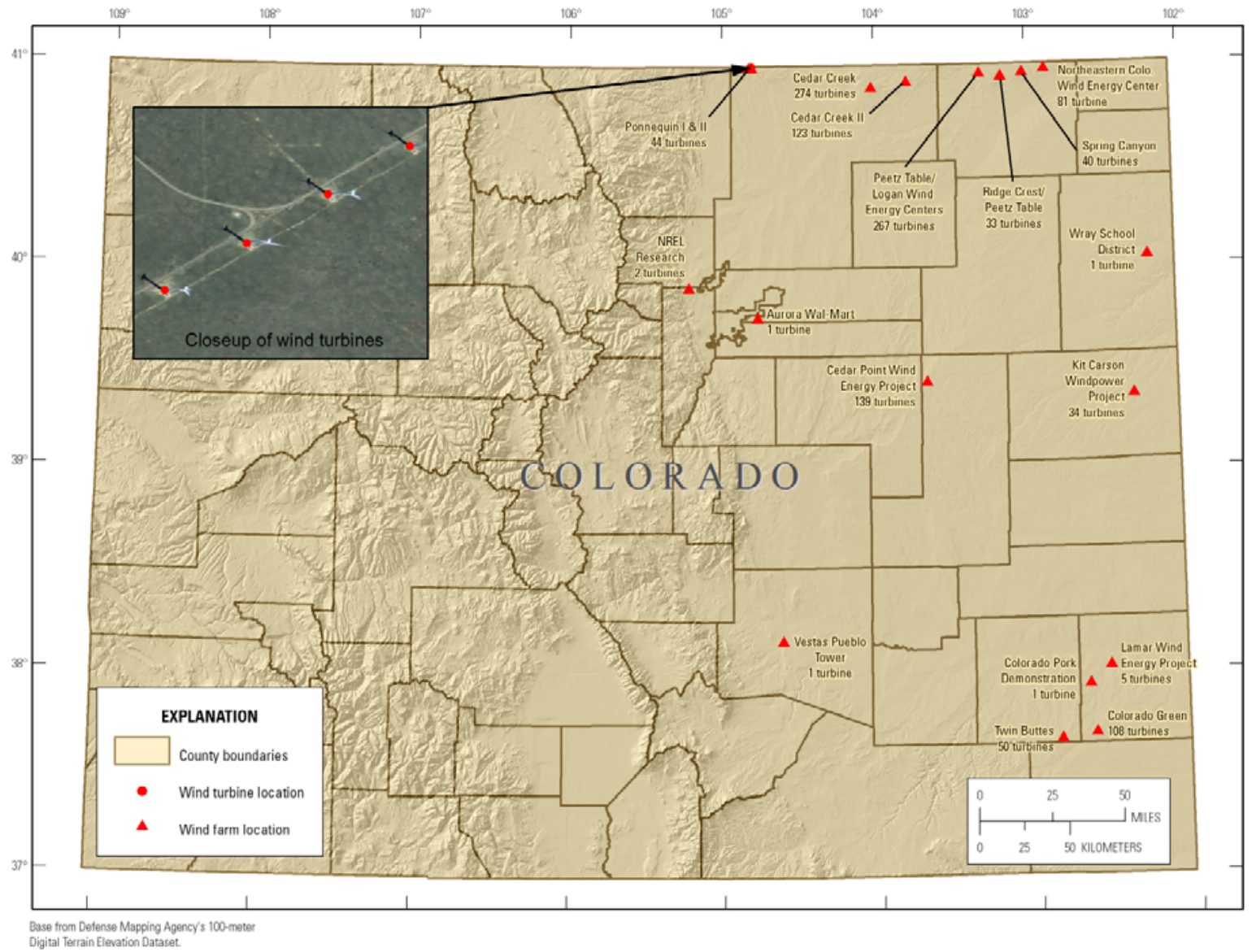

Figure 1. 2011 wind farm locations in Colorado. Locations of wind turbines (see inset image) and associated attributes are included in the dataset.

Suggested citation:

Carr, N.B., Diffendorfer, J.E., Fancher, Tammy, Hawkins, S.J., Latysh, Natalie, Leib, K.J., and Matherne, A.M., 2013, Locations and attributes of wind turbines in Colorado, 2011 [abs.]: U.S. Geological Survey Data Series 782, http://pubs.usgs.gov/ds/782/.

For more information concerning this publication, contact:

Center Director, USGS Fort Collins Science Center

2150 Centre Ave., Bldg. C

Fort Collins, CO 80526-8118

(970) 226-9398

Or visit the Fort Collins Science Center Web site at:

http://www.fort.usgs.gov/ 